\title{
Materia Medica Tocharo-Hvatanica
}

\author{
Federico Dragoni ${ }^{1}$ \\ Leiden University Center for Linguistics, Leiden, The Netherlands \\ f.dragoni@hum.leidenuniv.nl
}

\begin{abstract}
The two languages once spoken in the oases in the North of the Tarim basin, Tocharian $\mathrm{A}$ and $\mathrm{B}$, have preserved many Iranian loanwords. These belong to different chronological layers and are of different dialectal origins. Whereas the oldest layers are now most likely seen as belonging to an unattested Old Iranian dialect, more recent layers have not yet been studied in detail. In this respect, the vocabulary of medical texts represents an important field of enquiry. Most terms come from Middle Indian, but a significant number are of Middle Iranian origin. This component, mostly ingredients and technical vocabulary, seems to be largely of Khotanese origin. The article introduces the material and examines possible scenarios for historical transmission and contact between the North and the South of the Tarim Basin.

Keywords: Tocharian medical terms, Khotanese, Language contact, Silk Road studies, Medical literature in Central Asia, Middle Iranian linguistics
\end{abstract}

\section{Introduction}

Tocharian vocabulary contains a large number of Iranian loanwords, belonging to different chronological layers and of different dialectal origins (Peyrot 2015). The oldest layers are now most likely seen as belonging to an otherwise unattested Old Iranian dialect (Peyrot 2018), rather than to a reconstructed "Old Sakan" (Tremblay 2005). More recent layers of borrowings, however, have so far received little or no attention. The medical vocabulary is in this respect emblematic. Whereas most technical terms are of Middle Indian origin, a significant number are Iranian (Carling 2007: 330). The scholarly literature on the subject tends to view the Iranian component as being overwhelmingly of Khotanese origin. If this is true, it will enable us to uncover scenarios of historical transmission and contact between the North and the South of the Tarim Basin.

1 This research was supported by the Netherlands Organisation for Scientific Research (NWO, project number 276-70-028). I would like to thank Michaël Peyrot, Mauro Maggi, and the two anonymous reviewers for their constructive criticisms and comments. I am also grateful to Chams Bernard, Alessandro Del Tomba, and Niels Schoubben for commenting on an early draft of this paper. 


\subsection{Siddhasāra and Yogaśataka}

The preface to the Khotanese Siddhasāra, ${ }^{2}$ the great medical work preserved also in Sanskrit (Emmerick 1980) and Tibetan (Emmerick 1982), may offer us a rare glimpse into the reception of medical texts in Central Asia:

yauga-mālyo jsa yuḍāmdä śau-kșīrä krra.

apaysāṃä āchai cvai nayä ni bvīra. * viysam dūṣä' kālä u rve hamdari pātcä. pijsanīra-m aprrasama arve muḍa phari satva 5
"By means of collections of prescriptions they performed (medical) practice in the whole country. ${ }^{3}$ Disease (was) unrecognised because they did not know the theory of it: the unequal humour, time and seasons, (their) intervals too. Inappropriate medicines struck them down: many beings died." (Emmerick 1983: 20-1)

It was R.E. Emmerick's idea (1983: 22) that the "collections of prescriptions (yauga-mālyo jsa)" could refer to the Yogaśataka, "which was popular not only in India and Ceylon but also in Central Asia". 4 Such a reading of the passage is well worth considering, although I have not found any mention elsewhere of a rivalry between the Yogaśataka and Siddhasāra traditions. No Yogaśataka manuscript has been found in the South of the Tarim basin, but this is not sufficient to justify such an enmity. Moreover, Siddhasāra traditions are present in the North, although they are quite late..$^{5}$ It is possible, however, that the polemic passage of the Siddhasāra does not refer to a contrast between Southern and Northern oases. It could simply remind the reader of the contraposition existing between longer works that explained the medical theory and the popular collections of recipes such as the Jivakapustaka, which were clearly made for practical use. ${ }^{6}$ At any rate, if Emmerick's idea proves right, the preface of the Khotanese Siddhasāra might witness the late echoes of a contact scenario between the South and the North, which was already taking place at the time of the first Tocharian translation of the Yogaśataka in the North. ${ }^{7}$ One could surmise that not only the Yogaśataka, but also other medical texts, were circulating widely between the South and the North. This could have been the reason why the Tocharian medical lexicon seems to be so composite, and the Iranian part appears to be overwhelmingly of Khotanese origin. ${ }^{8}$ In such a contact scenario, one should obviously not underestimate the oral component, as pointed out by Carling (2007: 332).

2 See KT I: 2-134 and Emmerick unpublished. It was translated directly from the Tibetan and collated with the Sanskrit version (Maggi 2009: 415-6).

3 Lit. "one-country", probably referring to Khotan.

4 In the North of the Tarim basin we have fragments of a Tocharian translation, see Carling 2003.

5 For the extant Old Uyghur fragments, see Zieme 2007. Moreover, the Jivakapustaka seems to be extant in Tocharian, see Maue 1990. For medical literature in Sogdian, see Reck and Benkato 2018 for a complete survey of the extant manuscripts. Noteworthy is a fragment with a translation of Vāgbhața's Aștāngahrịdayasamnitā (Reck and Wilkens 2015).

6 This is how Maggi (2009: 416) interprets the Siddhasāra passage.

7 The extant Tocharian fragments could be approximately dated to the late VII/VIII c. AD.

8 H.W. Bailey in 1947 had already alluded to contact between the South and the North: "The Annals of Khotan and the Krorayina documents show that the Khotanese had 
In what follows, the Tocharian medical vocabulary of alleged Khotanese origin will be presented and analysed, in an attempt to verify whether such a contact scenario has to be assumed or not.

\subsection{The Tocharian medical vocabulary of alleged Khotanese origin}

Twelve medical lexical items have been selected. A distinction can be made between names of ingredients and technical vocabulary. Individual studies will attempt to verify whether the items have a clear Khotanese origin. Among the ingredients, we find:

- TB añkwaș(t) subst. 'Asa foetida'

- TB eśpeșse subst. 'spreading hogweed (Boerhavia diffusa)'

- TB kuñi-mot subst. 'wine'

- TB kuñcit kwäñcit A kuñcit subst. 'sesame'

- TB kurkamäșse kwärkamäșși adj. 'pertaining to saffron'

- TB tvānkkaro subst. 'ginger'

In the following, the items belonging to the technical vocabulary are listed:

- TB ampoño subst. 'rottenness, infection'

- TB ampa- v. 'to rot, decay'

- TB krāke A krāke subst. 'dirt, filth'

- TB krāk- 'to be dirty'

- TB spakiye subst. 'suppository'

- TB sanapa- v. 'to rub in, rub on, anoint, embrocate (prior to washing)'

It is important to note the presence of three verbs in this group, a feature that might suggest deeper linguistic contact (Thomason 2001: 70).

\section{Names of ingredients}

\subsection{TB ankkwaș(t) subst. 'Asa foetida'}

Tocharian occurrences:

- amkwwaṣ PK AS 2A a5, ankkwaṣ PK AS 2A b2. ${ }^{9}$ Both forms appear in a list of ingredients belonging to the Tocharian bilingual (Sanskrit-Tocharian) fragments of the Yogaśataka. The Sanskrit equivalent is hingu- 'id.' ${ }^{10}$ in both cases (Tib. sin-kun).

- anwașt PK AS 3B b5. ${ }^{11}$ The word appears again in a list of ingredients, although the text has not yet been identified. It was classified as a

close connexions with the cities of Kashgar, Kuci, Argi and Krorayina in political matters. Linguistic interchange was inevitable" (Bailey 1947: 150).

9 The text is not really late but shows at least the secondary wiralom for Skt. vida-lavana'salt' and curm for Skt. cürna- 'powder'.

10 On the Sanskrit word, which is probably an Iranian loanword, see KEWA III: 593 and EWA III: 538.

11 PK AS 3B is not an archaic text. For example, it has later sātke 'remedy' (next to original samtke) and later klyiye for kliye 'woman'. However, it does have cūrnä (for later curm, if cürnä is not a Sanskritism) and anwașt, which looks older because $-k$ - is not written. 
medical/magical text. The title of the section to which the text should refer is given in line b4 as a generic bhütatantra "Treatise against the demons".

Khotanese occurrences:

- In the Siddhasāra it occurs in various orthographic shapes: amguṣdä $\mathrm{Si}$ 19r4, 128r4, 130v2, amgūṣdą' 123r1, amgūus ḍi 126v4, amgūṣdi' 126r4, amgūuṣ̣ä 10v1, 12v4, 123r5, 124v1, agūṣ̣ä 122r4, amgauṣ̣̆ä Si P 2892.82 and 127.

- In the Jivvakapustaka: amgūṣdi Ji 56r4, amgauṣḍ 97r5, amgauṣdi 52r1, 98r2, 98v2, 100v2, amgauṣ̣ä 61v5, 85v3, 104v5.

- In other medical fragments: amguṣdi P 2893.219, amguṣdi P 2893.165. ${ }^{12}$

The scholarly literature agrees on the Iranian origin of the Khotanese word and posits a Proto-Iranian form *angu-jatu-. ${ }^{13}$ This is seen as a compound of *angu'tangy, sour' (Bailey 1957: 51) and *̌atu- 'gum' and is continued by New Persian angu-žad. ${ }^{14}$ From the occurrences in Late Khotanese medical texts, a Khotanese stem amguṣda- can be safely reconstructed as the original. ${ }^{15}$ As pointed out by an anonymous referee, PIr. *-jat- $>\mathrm{Kh}$. $-s d-$ is not a regular sound change in Khotanese. The regular outcome would probably have been **angujsata- with PIr. *-j- > Kh. -js- (cf. OKh. pajsama- < PIr. *upa-jama(Skjærvø 2004: II 293)). The first necessary step in order to obtain the Khotanese form is a syncope of the $-a$ - in $* * 0 j s a t a-$, which would have caused secondary contact between $*^{*}-j s$ - and $*^{*}-t$-. Such a contact, however, results in the cluster $-y s d-$, and not $-s d_{-}$, as one can easily see in the formation of the 3sg. pres. mid. of type B verbs (SGS: 193), e.g. dajs- 'to burn' 3sg. pres. mid. daysdi (SGS: 43) and drjs- 'to hold' 3sg. pres. mid. drysde (SGS: 46). -sd- (/zd/) seems to point to secondary contact of original $*_{-} \check{s}^{-}\left(>^{*} *_{-} \check{z}_{-}\right)$and $*_{-} t-{ }^{16}$ e.g. pyūș- 'to hear' 3sg. pres. mid. pyūṣde (SGS: 87).

In view of these problems with a derivation of amguṣda-from Proto-Iranian directly, it is preferable to see in LKh. amguṣda- a loanword from an Iranian language in which intervocalic $*_{-j}-$ underwent fricativization $\left(>*_{-} \check{z}_{-}\right)$. This might be

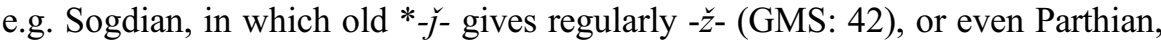
for which the same sound change is attested (Durkin-Meisterernst 2014: 96). Although highly speculative, a Sogdian or Parthian form might also be at the origin of the irregular -ž- found in New Persian angu-žad, which seems to alternate with a native form with $-z-\left(\right.$ angu-zad, Hassandoust 2015: I $n^{\circ}$ 525).

The dating of the syncope is crucial to determining whether the Tocharian form was borrowed directly from the unattested Sogdian (or Parthian, or another,

This is a graphic phenomenon associated with older stages, but without phonological relevance (Peyrot 2008: 178).

12 The edition of P 2893 is to be found in KT III: 82-93.

13 See DKS: 1, Bailey (1957: 50) and Rastorgueva and Èdel'man (2000: 166).

14 See Hassandoust (2015: $\mathrm{I}^{\circ}$ 525). Compounds with another second member are also present, cf. angu-yān (Hasandoust 2015: I $\mathrm{n}^{\circ}$ 535) and angu-dān (Hasandoust 2015: I ${ }^{\circ}$ 523), all meaning 'Asa foetida'.

15 For the Late Khotanese alternations $u: \bar{u}$ and $u$ :au cf. Dresden (1955: 406 [4], [5]).

16 See in detail Maggi 2019. 
unknown, Middle-Iranian language of the area) cognate that may be posited, or from Khotanese. It seems that the attribution of the syncope to Khotanese is not problematic: $-a$ - was first weakened ${ }^{17}$ to $-\ddot{a}$ - in unstressed syllable (*angùžata- > *angùžäta-) and then lost. Moreover, New Persian angu-žad, if borrowed from Sogdian or Parthian, may show that the unattested form had no syncope (although this is far less certain). In other words, the Tocharian form needs a source language in which syncope has already taken place. This may be identified with Khotanese, in which the loss of $-a$ - can be accounted for without problems. More questionable would be the possibility that loss of $-a$-was already realized in the unattested Middle-Iranian antecedent. Therefore, the chance that the Tocharian form was borrowed directly from Khotanese may seem higher than the possibility that Tocharian borrowed from Sogdian or Parthian. Nevertheless, this second possibility cannot be excluded.

As far as Tocharian is concerned, Iranian $*-u$ - was reinterpreted as $w+\partial$ and, more precisely, as $k^{w}+\partial$, so that the word takes the aspect /ank ${ }^{\mathrm{w}}$ 'șt $/$. This phenomenon is to be observed also for a series of other Tocharian medical terms (TB kuñcit $\sim$ kwäñcit, kurkamäșse $\sim$ kwärkamäșși and kwarm < Skt. gulma-). ${ }^{18}$ Since the development of $u$ to $u \sim w \ddot{a} \sim w a$ is thus understandable within Tocharian, the form may be derived from Khotanese without any problem. ${ }^{19}$ The form anwașt with final $-t$ is older than the form without $-t$, as ankwas can be derived from the form with final $-t$ by sound law (Peyrot 2008: 67).

Old Uyghur ' $n k$ 'pwš (Röhrborn 1979: 145), i.e. angabuš, probably via *anguwaš, with the absence of final $-t$ as in Tocharian, and Chinese 阿魏 $\bar{e}$ $w e i^{20}$ share the same semivocalic element $-w$ - and must therefore be considered Tocharian loans. The history of the word ${ }^{21}$ may thus be provisionally reconstructed as follows: Proto-Iranian *angu-jatu- $>*$ Sogdian (or *Parthian?) [*-j-

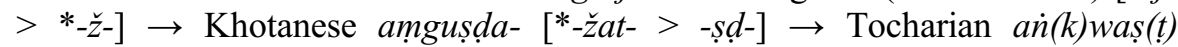
$[-k w a s ̦ t<-g u s ̣$ - $] \rightarrow$ Chinese and Old Uyghur (independently).

\subsection{TB eśpeșse subst. 'spreading hogweed (Boerhavia diffusa)'}

Tocharian occurrences:

- eśpeșse THT 500-02 b9-10.22 Otherwise, the more common word for the Boerhavia diffusa is punarnap, LW < Skt. punarnavā, in PK AS 3A a5,

17 On such weakening see Emmerick 1989: 211.

18 This alternation has already been noted by Isebaert (1980: 73-5). Tremblay (2005: 438) claims that PIr. *angu-jatu- has undergone a metathesis that resulted in *anguajt, further adapted to Tocharian phonology in the form ankwas $(t)$. However, this explanation is impossible because no vowel /a/ is present in the second syllable of the Tocharian form (the spelling $<\mathrm{a}>$ rather denotes /ó/). See further sections 2.4 and 2.5 .

19 Cf. already Bailey 1957: 50 fn. 2.

20 As noted by Samira Müller (personal communication), the first attestations of the Chinese word are from the Tang dynasty (see also Laufer 1919: 358-61). Accordingly, the Tocharian spelling squares with the reconstructed Middle Chinese form Pa-ngjwijH. See further Baxter and Sagart (2014: 121) for the reconstruction of the second character.

21 See further DoT: 7; Laufer 1919: 361; Bailey 1937: 913; 1946: 786; Henning 1965: 8 [= SelPap II, 604].

22 Medical, see Maue 1990. 
W19 b1, W1 b4, W6 a6, W6 b5, W17 b5, W20 a5. Another hapax legomenon for the same plant is wärścik, LW < Skt. vrśsika-, in PK AS 3A a5.

Khotanese occurrences:

- The Khotanese equivalent occurs various times in the Siddhasāra and in

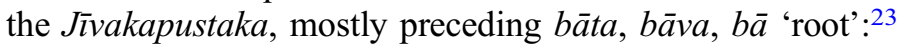

- Siddhasāra: aiśca bāva 100r4, eśta bāta 133r2, eśtä bā 135v2, e’śte bāta 129v2, e'śte bāta 135v3, auśta bāta 9v5, auśte bāta 140r2, au'śte bāta 139r5, au'śtä bāta Si P 2892.71.

- Jivvakapustaka: aiśta bā 49r1, aiśta bāva 58v3, aiśta bā 62v2, auśta bā 66r5, iṃśta bā 73r5, iṃśta bāva 77v3, iṃśta bāva 84r4, äṃśta 80v5, iṃ'śta bāva 79v2.

- In other medical texts: u'śtä bāva P 2893.213.

The Khotanese occurrences are attested in a puzzling series of different orthographies. It is immediately clear that such a vowel alternation in the first syllable is unprecedented, and therefore difficult to assess:

$\begin{array}{lllllllll}\text { iṃ- } & \text { äm- } & \text { ai- } & \text { e- } & \text { e'- } & \text { au- } & \text { au'- } & \text { u'- } & \text { Total } \\ 1 \times & 1 \times & 4 \times & 2 \times & 2 \times & 2 \times & 2 \times & 1 \times & 15\end{array}$

Five of fifteen total occurrences show a back vowel $(a u-, u$-), whereas the rest point to a front vowel $(i-, a i-, e-)$. H.W. Bailey's tentative explanation (DKS: 48) takes the forms with back vowel as original and posits a hypothetical $* \bar{a}$-vasty $\bar{a}-{ }^{24}$ However, this leaves the forms with front vowel, i.e. the large majority, unexplained. The subscript hook, which occurs five times, might signal the earlier presence of a lost $-l-$, as in the case of OKh. balysa- and LKh. ba'ysa-, be'ysa-, bi'ysa-, bai'ysa-. Only a few occurrences of the word have a subscript hook, but in the case of $b a^{\prime} y s a-$, too, the subscript hook is often omitted. ${ }^{25}$ Indeed, the presence of both front and back vowels in the Late Khotanese notation might also point to a lost $-l-$, which is normally associated with fronting, as noted by an anonymous peer-reviewer. The case of hälsti- 'spear', however, which occurs in Late Khotanese both with initial $h a$ ' and $h u$ ' (DKS: 486), apparently shows that loss of $-l$ - could also be associated with a back vowel. For the Khotanese word for Boerhavia diffusa, a hypothetical Old Khotanese form *alsta or *älśta can be then reconstructed. *älśta could be further interpreted as an inflected form of a stem *älsti-, a variant of OKh. hälsti- (SGS: 288) without initial $h$ - (< PIr. *Hršti- 'spear', cf. Av. aršti- and OP řšti- 'id.'). ${ }^{26}$

The use of terms for 'spear' to describe plants with reference to the oblong form of their leaves is documented in Latin, where the adjective lanceolatus 'lanceolate' is used as a botanical term. Since the leaves of the Boerhavia diffusa are not oblong or spear-shaped, the term may refer here to the form of its roots.

23 These are all different orthographies for the original $b \bar{a} g \bar{a}$ - 'root' (see DKS: 274-5).

24 With "Avestan $a v \bar{o}$ "herb".

25 See e.g. beysa, quite frequent in the Late Khotanese Aparimitāyuhsūtra (Duan Qing 1992: 125).

26 Kümmel (2018) discusses whether initial $h$ - is to be interpreted as an archaism (preservation of the Proto-Iranian laryngeal) or as a 'prothetic' $h$-. 
However, given the tentative nature of this explanation, there is always the possibility that the word could represent a borrowing from an unknown language.

Adams (DoT: 104) compares the Khotanese word with Tocharian eśpesse. The meaning is secured by the Khotanese and Sanskrit parallel (Maue 1990: $163 \mathrm{fn} .20)$. If -sse is an adjectival suffix, then we are left with something that closely resembles the Khotanese word, although Tocharian -śp- for Khotanese -st - is not paralleled elsewhere. A possibility to obtain the cluster $-s p$ - would be to consider the Tocharian word as a compound from LKh. *aiśti- $+* b \bar{a}(g a)>*_{a i s ́} t a ̈ b \bar{a}>*^{*}$ aiśtba $>\mathrm{TB}$ eśpe. ${ }^{27}$ However, this leaves the Tocharian vocalism of the final syllable unexplained, since it is very unlikely that LKh. $<\overline{\mathrm{a}}>$, which probably had the value /o/ (Emmerick 1979: 245 ), could have resulted in TB -e-. Overall, the comparison seems rather doubtful.

\section{3. kuñi-mot subst. 'wine'}

Tocharian occurrences:

- $\quad k u n ̃ i-m o t$ IOL Toch 305 b1 (literary)

- kuñi motässse W20 a4 (medical)

- kuñi motsa W22 a3 (medical)

- $k u \tilde{n} i * m o t^{28} \mathrm{~W} 38$ a6 (medical)

Khotanese occurrences:

- gūra- 'grapes' e.g. in Siddhasāra 12r2.

- gūränai mau 'grape wine' P 2895.29 (Paris Y). ${ }^{29}$

Adams (DoT: 193) puts forward the hypothesis that the first part of the word may derive from LKh. güränaa- (KS: 142), adjective to güra- 'grapes', with loss of the medial syllable. LKh. güränaa- is an adjectival formation which was formed with the suffix -inaa- (PIr. *-ainaka-). The long $-\bar{l}-$ of the suffix was shortened to $-i$ - or $-\ddot{a}$ - in unstressed position. This phenomenon may be part of a more general tendency of vowel weakening before the nasal $-n$-, which is already attested in Old Khotanese (KS: 136). For the adjective güränaa-, therefore, a proto-form *gudrainaka- may be reconstructed. If TB $k u \tilde{n} i$ is really derived from the adjective güränaa-, we must reckon with a loan from Khotanese, after the shortening of the long $-\bar{l}$ - of the suffix (already Old Khotanese) and the loss of intervocalic $-k-: k u \tilde{n} i<g \bar{u} n i<g \bar{u} r n \underline{i}<\mathrm{LKh}$. gūränai (< PIr. *gudrainakah). At first sight, Adams' suggestion might appear rather far-fetched. However, the occurrence of the adjective güränaa- with mau 'wine' in the Late Khotanese lyrical poem contained in the manuscript P $2895^{30}$ might support his hypothesis. Indeed, the parallel TB kuñi-mot $\sim$ LKh. güränai mau seems rather striking. The Tocharian B form would then be a partial calque with TB kuñi < LKh. güränai and TB mot for LKh. mau. As suggested by the

27 LKh. $a i$ - (for /e/) may stand for TB $e$ - without problems, see Dresden 1955: 406.

28 Cf. Filliozat (1948: 78 fn. 1) for the emendation.

29 See KT III: 41 1. 29.

30 The passage is also quoted in Bailey (1957: 51 fn. 2) and DKS: 87. 
reviewer, it might be worth noting here that TB mot cannot have been borrowed from Sogdian, as stated e.g. by X. Tremblay (2005: 438). The form $m w \delta y$ quoted by Gershevitch (GMS: 408) from the Ancient Letter IV, 1. 5, is now recognized to mean 'price' $\left(\mathrm{LW}<\mathrm{Skt}\right.$. mülya-). ${ }^{31}$

\subsection{TB kuñcit kwäñ cit A kuñcit subst. 'sesame'}

Tocharian occurrences:

- $\quad$ TB kuñcit PK AS 3A a1; a3 (medical), PK AS 8C a7 (medical), THT 18 b5 (2×) (doctrinal), THT 3998 a3 (wooden tablet), W7 a6 (medical);

- TB kuñcitä THT 505 b2, THT 2676 b3;

- TB kwäñ citä THT 1535.c b3 (literary);

- TB kwäñcitșa adj. (?) THT 1535.e b3 (literary);

- TB kuñcitäsșe adj. 'made from sesame' IOL Toch 306 a5 (medical), PK AS 2B a6; b4, PK AS 2C b6, PK AS 3A a6, PK AS 3B a2; b1 (Yogaśataka), PK AS 9B b6 (medical), THT 364 b1, THT 2677.d b1 (literary), W10 a3; a4, W19 b3, W24 a3 (medical);

- TB kuñcītäsșe adj. THT 27 a8 (doctrinal), THT 497 b4; b9, W4 a4; b2, W6 b1, W21 b2, W23 a2, W27 a3; b3, W30 b4, W31 b2, W33 b2, W34 a4, W35 a5 (medical);

- TB kuñcītașşe adj. THT 497 b5 (medical);

- TB kuñcitäșe THT 2348.i b2 (literary), THT 2347.a a2, b3 (literary);

- TA kuñcitși adj. 'pertaining to sesame' A 103 a5, A 152 a3, A 153 b6 (literary);

- $\quad$ TA kuñcit PK NS 2 a2 (medical);

- TA kuñcitaśśäl PK NS 3 b1 (medical).

The TB -sṣe adjective can refer to milk (malkwer), oil (salype) or taste (śūke, only in THT 27, not medical).

Khotanese occurrences:

- In Old Khotanese the form is kumjjsata- 'sesame', in Sañghạtasūtra 72.2, $73.1,88.2,72.2 .^{32}$

- The most frequent form in Late Khotanese is kumjsa-, in Siddhasāra 9v1, 16v2, 100r3, 101v2, 106r3, 132v3, 133r2, 142v1, 142v5, 143r1 (10x), Si P 2892.60, in other medical texts P 2893.35, 46, 48, 80, 89, 113, 120, $127,131,147,158,211,218$, IOL Khot. S. 9.2, 24, 31, 35, 40, ${ }^{33} \mathrm{P}$ 2781.29, in documents P 103.52 col. 2.1 (SDTV: 158). Without anusvāra (kujsa-) in Siddhasāra 9r4, P 2893.247, 251, 255, 262, KT IV: 26.4, 5, P 103.26.1, kāmjsa in P 2893.235 and in the documents P 94.8.4 (SDTV: 98), P 94.23.4,7, P 95.6.2, P 96.4.2, P 96.4.3, P 97.3.2,

31 See Benveniste (1946: 98) and Sims-Williams (1983: 45). A form $m w d[$ with $-w$ - does exist, but it is attested only in the very late gospel lectionary E5, for which see Barbati (2016: 237), as kindly remarked by the reviewer.

32 Numbers refer to the edition in Canevascini 1993.

33 = Ch. 00265, see Skjærvø 2002: 487. It is to be inserted between P 2893.91a and 91b, see Maggi 2008. Maggi (2018: 251 fn. 30) names the resulting medical text "Piṇụaśástra". See further Luzzietti 2018-19: 29-33. 
$\mathrm{P}$ 98.6.5, $\mathrm{P}$ 98.7.1, $\mathrm{P}$ 103.5.2,7, $\mathrm{P}$ 103.5.4, $\mathrm{P}$ 103.5.8, kājsa in P 95.5.6, kumjsa in Ji 95r3, kumjsamnna $\mathrm{P} 2893.56 .{ }^{34}$

- The Old Khotanese adjective kumjsatinnaa-, ${ }^{\circ} \bar{i} m g y \bar{a}-$ 'pertaining to sesame' is to be found in Sanghātasūtra 73.2, 37.3, 28.4, 73.1, 74.2, 88.2, 28.3, Śurañgamasamādhisūtra 3.14r3, 3.13v2; 4, ${ }^{35}$ IOL Khot 34/2.a1 and IOL Khot 41/1.9.

- The Late Khotanese form of the same adjective is mostly kumjsavinaa-: kumjjavinā Si 139r2, 141r1, kumjsavīni Ji 97r2, 97v1, 96v4, 98r2, 98v2, 99v2, kumjjavini Ji 99r4, 101v3, kuṃjsavīnai Si 15r1, 100v2, 101r3, 104v1, 109v5, 129v4, 130r2, 144r1, 156r1, 156r4, P 2893.165, kumjsaquinai P 2893.139, without anusvāra kujsaviña Si 155r4, kujsavīña Si 153v4, kujsavinai Si 128r2, 128r4, 128r4, 130r3, 130r4, 131r2, 141r3, IOL Khot. S. 9.22, 110, P 2893.167, 256 kujsavįnai Si 129r5, P 2893.179, kujsavinya Si 141r2.

- kumjsārgye 'sesame oil-cake' in Si 9r5, P 2893.83.

The most recent Tocharian lexicographical works consider the word a loan from Khotanese. ${ }^{36}$ This communis opinio is probably to be traced back to a note by H.W. Bailey (1937: 913). However, he does not state directly that the form is Khotanese. He writes rather that the Tocharian B word represents "an older stage than Saka kumjsata-". He further derives the Khotanese form (DKS: 61) from a reconstructed *kuncita-, which is based on Skt. kuñcita-, even if this seems to be used for another type of plant, the Tabernaemontana coronaria. $^{37}$ In fact, the Tocharian and Khotanese occurrences both in the Yogaśataka and in the Siddhasāra translate Skt. tila- 'Sesamum indicum', (KEWA I: 504), not kuñcita-. Tremblay (2005: 440) does not give any identification more precise than "Middle Iranian". If the form is really Iranian, it might not be easy to find out if the Tocharian word actually derives from the protoform *kunčita-, which seems to be at the origin of Sogdian kwyšt' $y c,{ }^{38}$ Khotanese kumjsata-, Old Uyghur künčit ${ }^{39}$ and Middle Persian kwnc(y)t (CPD: 52). For what concerns Pashto kunjála, an Indian origin is preferred by Morgenstierne. ${ }^{40} \mathrm{He}$ further extends his hypothesis to all Iranian forms, which he considers old loans from Indian. In general, the Pashto form seems to share with Khotanese the voiced affricate and a different vowel in the second

34 Not to be read kumjsana, see Luzzietti 2018-19: 45-6.

35 The numbering follows Emmerick 1970: 43-7.

36 See Carling et al. 2009: 148 and DoT: 193.

37 See Böhtlingk and Roth 1855-75: II 70. The word seems to be attested only in lexicographical works. Variants of the same word, used to designate other plants, are kuñcika'Nigella indica' and kuñcī 'cumin'.

38 See Gharib 1995: 202. Henning (1946: 734 [= SelPap II: 252]) proposes the following: "kwyšt- (if $=$ sesame) $=$ kuišt $<*$ kuinšt $<*$ kuinčt $<*$ kunčit". A graphic explanation is preferred by Benveniste (1940: 180) (“Est-ce une mauvaise graphie pour *kwnšt-?"). The anonymous peer-reviewer noted that a form kwync' [ is also attested in P 29.9 (Sims-Williams and Hamilton 1990: 33), which seems to be phonetically closer to the forms occurring in the neighbouring languages.

39 An old loan from Sogdian, according to Tremblay 2005: 440 (?).

40 See Morgenstierne 1927: 33 and EDP: 39 "certainly" old LW < Indo-Aryan (Skt. kuñcita-) in Pashto. 
syllable instead of the expected $-i-.{ }^{41}$ Whereas the voiced dental affricate instead of the unvoiced palatal is regular in both languages, ${ }^{42}$ no satisfactory explanation for the different vowel is available.

On the whole, it might be difficult to trace the history of the word. Since the Indian forms are attested rather late and occur only in lexica, it is dangerous to reconstruct a Proto-Indo-Iranian form. In this case, Tremblay's general label "Middle-Iranian" seems the safest solution for the time being. ${ }^{43}$

\subsection{B kurkamäșṣe kwärkamäșși adj. 'pertaining to saffron'}

Tocharian occurrences:

- $\quad$ kurkamäsși PK AS 3B b5, THT 497 b8, THT 498 a8, W4 b1; b4, W7 b3, W19 b5, W20 a5, W21 b4, W26 b4, W32 a4, W38 a5, W39 a3, W41 b3 (all medical).

- kwärkamäșși W29 b1 (medical).

- THT 2676 a3 (kurkumä-) at the end of the line, it could also be restored as kurkumä(sșe) (Peyrot 2014: 139, fn. 47).

Khotanese occurrences (only Late Khotanese):

- kurkām Ji 97v3 and P 2893.62;

- kurkām P 2893.57;

- kurkum Si 10v2;

- kūrkām Ji 108r5;

- kūrkūm Ji 105v1;

- kürkūm Ji 44v1;

- kurkumīnā [...] prahaunä 'saffron [...] garments' KT III: $1.9 \mathrm{r} 5,{ }^{44}<\operatorname{adj}$. kurkuminaa- (KS: 141).

Here is not the place to reconsider the whole history of the word, which does not seem to be specifically Iranian and can be traced back in time as far as

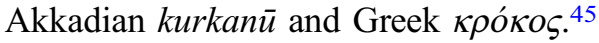

The basis for the Tocharian form must have been provided by an unattested *kurkuma-. As in the case of amkwașt and kuñcit kwäñ cit (cf. 2.1 and 2.4), $* k u$ was reinterpreted as $k^{w}+\partial$, so that we obtain the spelling $/ \mathrm{k}^{\mathrm{w}}$ ərk ${ }^{\mathrm{w}} \partial \mathrm{m} /$, further dissimilated to $/ \mathrm{k}^{\mathrm{w}}$ ərkəm/. This (*kurkäm) might have been the original form from which the adjective was derived through accent shift $\left(/ \mathrm{k}^{\mathrm{w}}\right.$ '́rkəm/ $>$ $/ \mathrm{k}^{\mathrm{W}}$ orkóm $\left.{ }^{\circ} /\right)$. The tiny fragment THT 2676 is one of the earliest Tocharian manuscripts (Peyrot 2014: 139 and Malzahn 2007: 267) and might have conserved the

41 C. Bernard (personal communication) draws my attention on Balochi kunčat (beside kunčìt and kunčit), quoted in Korn 2005: 192, which shows the same vowel as Khotanese.

42 Cf. OKh. hamjisaș- < PIr. ham-čaš- (SGS: 139) and Pashto anjór < PIr. *han-čāra(Morgenstierne 2003: 9). LKh. kumjū, which translates Skt. kāñcika- and Tib. rtsabs 'vinegar of rice, gruel' in Si 102r2 and 131r1, shows only the voicing; it must have been borrowed later than kumjsata-.

43 On this word and on the Tocharian alternation $k u \sim k w \ddot{a}$, see further Bernard 2020: 52-4.

44 The text is the Avalokiteśvaradhārani. See SDTV: 241-2 for edition and translation of the passage in question.

45 A very short summary with further references can be found in KEWA I: 219. 
undissimilated form $/ \mathrm{k}^{\mathrm{w}}$ ərk ${ }^{\mathrm{w}}$ əm/. Since all Indian forms (CDIAL: 3214, cf. Skt. kunkkuma-) have a nasal instead of the expected $-r$-, it is more probable that the Tocharian word derives from Iranian. Given the fact that saffron is known to grow in Persia (Laufer 1919: 320), a Middle Persian origin (Pahlavi kwlkwm (CPD: 52) and New Persian kurkum ${ }^{46}$ ) is suggested by Tremblay (2005: 437). Otherwise, the Middle Persian form might have reached Tocharian through Khotanese *kurkuma- (DKS: 63). In fact, this is the form which might be reconstructed for Old Khotanese based on the Late Khotanese occurrences. ${ }^{47}$ However, as noted by a referee, there is no special phonetic feature that might be attributed to Middle Persian proper. Tremblay's idea seems thus quite arbitrary and a Middle Persian origin remains highly doubtful. For the time being, it seems safer to consider the origin of the Tocharian word as coming from a general 'Middle-Iranian' context, without further specification. It might be noted further that Sogdian kwrkwnph, ${ }^{48}$ because of the final labial plosive, remains a less probable candidate. An Iranian origin has been also suggested for Tib. kur-kum (Laufer 1916: 474).

\subsection{TB tvāìkaro subst. 'ginger'}

Tocharian occurrences:

- twānkaro THT 497 a7; b5, PK AS 9B a4 (medical).

- twankkaro PK AS 9B b2 (medical). ${ }^{49}$

- tvānkaro PK AS 2A b2, PK AS 3B b5 (all Yogaśataka), PK AS 9A b7 (medical), THT 500-502 b7 (Jivakapustaka).

- tvānkaraimpa (com. sg.) PK AS 2B a2.

- tvānkaracce (obl. sg. m. of tvānkaratstse) PK AS 2A a6 (medical). ${ }^{50}$

Khotanese occurrences:

- ttüṇgara Ji 78v4, 82v3, 88r2, 93v3, 98v2, 99r3, 99v2, 99v3, 101v2, 106v4, 109r5, 11v1, 112r4, 115r2, 115v5, 116r5;

- ttūgara Ji 98r2;

- ttūmgara Ji 58v2;

- ttūmparä Ji 88r4, 106r4, 110r3, 111r1, 113r1, 115r5;

- ttūgarä Ji 87r2;

- ttūṃarām Si 130v5;

- ttūgare Ji 57r4;

- ttūmgare Si 146r2;

- tūmgare Si 101v5.

46 See Hassandoust 2015: IV $\mathrm{n}^{\circ} 3955$.

47 For the alternation $-\bar{a} m /-\bar{u} m$ and $u / \bar{u}$, usual in Late Khotanese, see Dresden 1955: 406 [2] and [4].

48 P 3.173, 271 (Benveniste 1940: 67 and 71).

49 Since the text has older forms, $<\mathrm{a}>$ for /á/ might be an archaic feature, rather than simply a mistake.

50 Since no phonetic explanation is available, $<\mathrm{v}>$ for $<_{\mathrm{w}}>$ might simply signal that the word had a foreign association. For another view, see Malzahn 2007: 270. 
H.W. Bailey's initial idea (1937: 913) sought to explain TB $-v \bar{a}$ - against Khotanese - $u$ - by comparing TB aíkwaș(t) and Khotanese amgușda-, simply taking note of the same correspondence, without offering any further explanation. This is not possible because the Tocharian form contains here clearly /wá/ $(<w \bar{a}>)$ and not /wá/ (<wa $>$ ) for /u/ as in a $k$ kwașt (see 2.1). Some time later, however, he developed a new etymological proposal. ${ }^{51} \mathrm{He}$ derived the Khotanese word from *tuwam-kara- with *tuwam ${ }^{\circ}$ from the Proto-Iranian root *tauH- 'to be strong, swell' (Cheung 2007: 386). In this case, the Tocharian form would have conserved the Pre-Khotanese state of affairs and should be considered as a very old loan (Tremblay 2005: 428 and DoT: 343). Bailey's derivation seems to imply a nominal form *t(u)v-a-from the verb *t(u)v- 'to be strong' (DKS: 144). This root is attested as verb with causative suffix $-\bar{a} \tilde{n}-$ in LKh. $t v-\bar{a} \tilde{n}-$ 'to strengthen' (SGS: 41). Several nominal forms from the same root are also to be found as medical terms, e.g. LKh. $t v-\bar{a} \tilde{n}-\bar{a} k a-$ 'strengthener' (KS: 46) $)^{52}$ and LKh. $t v-\bar{a} m \bar{a}-(<* t v-\bar{a} m a t \bar{a}-)$ 'strengthening' (KS: 94). ${ }^{53}$ The case ending of the first member of the compound would have been preserved in the nasal $*_{-} m$ - before the second member *-kara-, as is the case in similar compounds, cf. e.g. dìramggāra- 'evil-doing' (SVK I: 56, Degener 1987: 39). This derivation, however, seems semantically difficult. $t v-a$ - must be a substantive (KS: 1$)$ with the meaning 'strong one', 'strong thing' or 'fat'. The resulting compound could be then approximately translated as 'maker of strong (things or beings)'. Admittedly, such an attribute would be suitable for a person, not for a plant. It would be then desirable to have an adjective as first member of the compound. This is indeed possible if one starts with a form $t v-\bar{a} n a-$, an -āna- derivative (pres. part. mid. KS: 78) from the root $t v-$, which could produce a proto-form *tvāna-kara- 'strong-maker'. This would yield OKh. *tvāmgaraa- ${ }^{54}$ through syncope of internal unaccented $-a-$. Both Old Khotanese reconstructed forms, *tv-am-garaa- and *tv-ām-garaa-, may have been antecedents of the attested LKh. ttümgara-, since both OKh. tva ${ }^{\circ}$ and $t v a^{\circ}$ may result in LKh. $t t \bar{u}^{\circ}$. For $t v \bar{a}^{\circ}>t t \bar{u}^{\circ}$ one may compare the possessive adj. OKh. tvānaa- 'your' (KS: 85) which occurs in LKh. as ttūnā (IOL Khot S. 15.11) and for $t v a^{\circ}>t t \bar{u}^{\circ}$ OKh. tvamdanu 'reverence' (SGS: 219) and its Late Khotanese counterpart $t t \bar{u} d a$ (IOL Khot S. 6.27). Both Old Khotanese reconstructed forms may as well have been borrowed into Tocharian B. There is indeed no need to consider TB tvāinkaro as a Pre-Khotanese loanword. The evidence suggests that the word may have been borrowed from the Old Khotanese antecedent of LKh. ttūmgara-. ${ }^{55}$

It might be worth noting that Tib. li don-gra, which translates Skt. nāgara'ginger' in the Siddhasāra (Emmerick 1985: 313 and Bielmeier 2012: 21-2) is

51 First proposed apud Ross 1952: 15. See also DKS: 130.

52 This is used as a medical term to describe the properties of an ingredient, cf. Si 16v3-4 cu mi' ña guśta [...] tvąã̃a ka 'As for sheep flesh, [...] it (is) a strengthener'.

53 Also a medical term, occurring in Si 144v1.

54 According to KS: 20, the second member *-garaa- $<*$-kara-ka- is only attested with $-k a$ suffix in Old Khotanese; the forms without it are all Late Khotanese.

55 The final $-o$ of the Tocharian B word seems now to be very frequent in loanwords from Khotanese. The analysis of this ending is the object of a thorough investigation in my $\mathrm{PhD}$ thesis. 
also a Khotanese loan. That the borrowing took place from Khotanese is made clear by the preceding $l i$, which always refers to Khotan (Laufer 1916: 455 fn. 1).

\section{Technical vocabulary}

\subsection{TB ampoño subst. 'rottenness, infection'}

Tocharian occurrences:

- ampoñamtse (gen. sg.) PK AS 3A a1; a6; b1 (medical);

- ampoññantse (gen. sg.) PK AS 3A a2 (medical);

- ampoñai (obl. sg.) THT 503 a3 (medical);

- ampoño (nom. sg.) THT 510 b6 (medical).

In the manuscript PK AS 3A it is used consistently in the gen. sg. with sāmtke 'remedy'. The text describes four remedies against ampoño. All other occurrences refer to medical texts.

Adams' second edition of his Tocharian B dictionary contains the following statement s.v. ampoño: “A nomen actionis from ämp- 'rot,' q.v., from Khotanese hambu-, i.e., hambu- + the Khotanese abstract-forming suffix -oña" (DoT: 21). In Old Khotanese there is indeed a word hambüta- occurring in Z 5.16 and $5.18,{ }^{56}$ two passages which present us with two literary similes involving medical terminology:

Z 5.16 trāmu māñamdu kho hvą'ndä hambūtä hambaḍ̈ ysūna

cvī ye ālìva nitcana ìndä samvī

ttaṃdu hamārgya

Z 5.18 samu kho hambbūvu bei'ttä . harbiśśś āchai jūye . trāmu nairätma-hvanaina uysnori ysamtha jyāre
"Similarly, in the case of a man's fester full of pus, when one puts ointments on it on the outside, there is only so much alleviation of it." (Emmerick 1968a: 99)

"Just as when one cuts open a fester all disease is removed for one, so through the doctrine of selflessness (nairātmya) births are removed for a being."

(Emmerick 1986: 73)

This has the aspect of a past participle from the Proto-Iranian root *pauH- 'to stink, smell, rot' (Cheung 2007: 302), to which a preverb *ham- has been added. ${ }^{57}$ In the corresponding stanzas of the Mañjuśrinnairātmyāvatārasūtra, the word appears regularly as $h a(m) b u$ in both occurrences, as one would expect in Late Khotanese. ${ }^{58}$ It is clear from a second set of occurrences in the Late Khotanese medical text P 2893 (KT III: 82-93) at lines 184, 185 and 189 that the word is a technical term. Here the word occurs in the spelling hambva()- (< hambuva- < hambüta-) always with the meaning 'fester'. The reference to 'hambu' in DoT: 21 seems to take into consideration only one of the Late Khotanese forms, without commenting on the Old Khotanese one, which should be first compared with Tocharian. Otherwise, 'hambu' might stand for *hambu- and might be a reference to the unattested present stem from which

56 Another Old Khotanese occurrence is to be found in Suv 18.91, see Skjærvø 2004: 336.

57 See also Emmerick 1989: 210 and 214 and Skjærvø 1994: 284.

58 P 4099.133 (for MS bahu) and 135, see Emmerick 1968a: 440. 
the past participle hambüta- is derived. However, the suffix -ūña-/-auña- can be added to past or present participles but there is no example with the suffix being added directly to a present stem (KS: 159). If one were to add it to hambüta-, one would expect *hambüttauña-, in line with the attested hämättauña(< past part. hämäta-) (KS: 164). The resulting intervocalic -t- seems to undergo strengthening rather than be lost altogether. However, one cannot exclude the possibility that intervocalic - $t$ - was lost in this case already in Khotanese. In fact, as suggested a referee, -tt- in the hapax hämättauña- might be an example of 'morphologische Verdeutlichung' (KS: 162), i.e. a way to stress the presence of a morpheme boundary before the suffix. If this is correct, one could see in ampoño the past part. LKh. hambva- to which the suffix -auña- has been added. This would confirm the hypothesis of a Late Khotanese origin of ampoño, as suggested by Adams.

From the Tocharian point of view, however, there is still the possibility that ampoño is a genuine Tocharian formation based on the verb TB ampa(borrowed from LKh. hambva-, see 3.2). In fact, all attested forms point to a nom. sg. ampoño or ampoña*. Because of the palatalization, ampoña would be the expected form (M. Peyrot, personal communication). THT 510, the fragment containing the only occurrence for ampoño, is normally classified as late, so the form might be simply interpreted as secondary for earlier ampoña (Peyrot 2008: 99-101). This form would have the appearance of a derivative in -'eñna from a verbal root, ${ }^{59}$ which in this case could be ampa- 'to rot' (see 3.2). For the forms with single $-\tilde{n}$ - for the expected $-\tilde{n} \tilde{n}$ - one might compare the obl. sg. of wșeññ, which is attested four times with a single $-\tilde{n}$ - (IOL Toch $117 \mathrm{~b} 4$, Km-034-ZS-R-01 a7, PK AS 16.7 a4, IOL Toch 62 a3).

\subsection{TB ampa- v. 'to rot, decay'}

\section{Tocharian occurrences:}

- THT 9 b7 stastaukkauwa ämpauwa spärkauw= ere : ·ai /// 'swollen, rotten, void of colour', parallel THT 10 a3 as preterite part. nom. pl. m. (doctrinal).

D.Q. Adams (DoT: 48) regards it as a Middle Iranian loanword from the same root as Khotanese hambūta-, New Persian ambusidan, etc. Malzahn (2010: 525) seems to be of the same opinion and would rather take the word as a Khotanese loanword. If from Khotanese, one might envisage the possibility that the form has the aspect of a denominative formation from LKh. hambva $(<\mathrm{Old}$ Khotanese hambüta-, see 3.1), resulting in TB amp(w)a-. This verb can be thus traced back with a fair degree of certainty to Late Khotanese.

\subsection{TB krāke TA krāke subst. 'dirt, filth'}

Tocharian occurrences:

- A krāke nom. sg.? A 211 a1, a3, THT 2494 a2, nom. pl. krākeyäntu THT 2401 a3, obl.pl. krākes A 152 a4 (all literary texts).

59 Cf. e.g. ścmoñña 'basis' and wșeñña 'dwelling place'. For the formation, see Peyrot 2010: 72. In this case, the root is attested as ampa-, see 3.2. 
- B krāke gen. sg. IOL Toch $4 k r(\bar{a}) k e(t) s(e)$ (doctrinal), IOL Toch 262 b4 (literary), PK NS 49B a2 (doctrinal, karmavibhanga), THT 7 a7; b2 (doctrinal), THT 159 b6 (abhidharma), THT 221 b4 (literary), THT 334 b1 (literary, vinaya, here it may refer to sperm $^{60}$ ), THT 388 a6, THT 408 b6 (both literary in THT 408 in the expression kleśanmașse krāke, "the filth due to kleśas'), THT 522 a4 (doctrinal), THT 537 b5 (doctrinal), THT 1118 (vinaya, snai krāke 'unstained'), THT 1192 a6 (literary, cmelșe krāke 'the filth pertaining to rebirth'), THT 1227.a a3 (literary, very fragmentary), THT 1258 a4 (literary), THT 2227 b1 (literary), W2 a6 (only occurrence in a medical text, ratre krāke 'the red filth').

The Tocharian A form is probably borrowed from Tocharian B.

Khotanese occurrences:

- OKh. khārggu acc. sg. Z 19.53.

- OKh. khārggä nom. sg. IOL Khot 150/3 r4 (Bodhisattva-compendium, Skjærvø 2002: 337).

- OKh. khārja loc. sg. Z 5.90 (kho ju ye viysu thamjäte khārja 'as one pulls a lotus out of the mud').

- LKh. khä'ja loc. sg. P 4099.355 (sa khu vaysa khä'ja sürai 'just like the clean lotus in the mud').

- LKh. khä'je loc. sg. Si 136v3, 136v4 (in both cases tr. of Skt. kardama-), P 4099.278 (sa khu veysa khä'je sürai 'just like the clean lotus in the mud').

- LKh. khāje loc. sg. P 4 12r4 (Adhyardhaśatikā, see SDTV: 29).

- LKh. khāji loc. sg. P4 12r4-5 (Adhyardhaśatikā, see SDTV: 29).

- LKh. kheja loc. sg. (with further fronting of -ā-) Jātakastava 27v4.

- LKh. khājaña- loc. sg. (see SGS: 262 for the ending) Jātakastava 23v2.

It seems that the first scholar to put forward this etymological proposal was Van Windekens (1949). Isebaert (1980: §180) finds the derivation unconvincing and suggests an Indo-European origin. His main criticism of Van Windekens' proposal is based on morphological reasons. According to him, Middle Iranian loanwords never receive the masculine $-e$. Whereas Bailey's Dictionary (DKS: 74) does not seem to take note of the possibility of a loanword, Tremblay (2005: 433) returns to Van Windekens' proposal and reports it without any further comment. The Khotanese word is formed from the Proto-Iranian root $* x a r d$ - 'to defecate' 61 to which the suffix $-k a$ - has been attached (KS: 181), resulting in *xardaka-. In order to obtain the attested forms, one has to assume a series of metatheses which took place very early, at least earlier than the sound change $-r d->-l$ - in Khotanese: *xardaka- $>$ *xadraka- $>$ *xadarka-. This might have been the base for Yidgha xəlaryo (from a feminine *xadarkā-, EVSh: 79) and Khotanese khārgga-, through loss of intervocalic $-d$ - and voicing of $-k-$.

60 Following Peyrot 2013: 694.

61 See Cheung 2007: 444. The verb is attested in Khotanese with preverb as samkhal(SGS: 130). 
Given the specificity of the formation, if the word is a loanword, it cannot come but from Khotanese. After all, it seems that Khotanese 'mud' refers to the same semantic areas of Tocharian 'dirt' and 'filth'. ${ }^{62}$ In this case, the Khotanese form would have undergone in Tocharian a further metathesis to become krāke.

\subsection{TB $k r a \bar{k}$ - 'to be dirty'}

Tocharian occurrences:

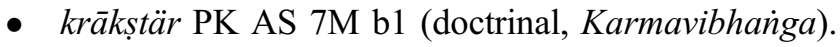

As reported by Adams (DoT: 229), the meaning 'to be dirty' was suggested by M. Peyrot (apud Malzahn 2010: 612) on the basis of the substantive TAB krāke, from which the verb is derived. The passage in question, which refers to poor, blurred eyesight, seems to justify such an interpretation.

\subsection{TB spakīye subst. 'suppository'}

Tocharian occurrences:

- spakiye THT 510 b1, W15 b3 (2×), W38 b5, W39 b1.

- spakaim W3 a3, W8 b4, W9 a3, W 10 a4, W34 b2, W42 b1 (all medical).

All occurrences of the plural come together with yamașällona, gerundive of yām- 'to make', e.g. in the phrase W3 a3 șpakaim yamașäallona 'suppositories are to be made'. This is exactly paralleled by the Khotanese technical phrase șvakyi padimāñä (e.g. Si 122r1, part. nec. of padim- 'to make'), with the same meaning.

Khotanese occurrences:

- șvaka Si 121v5, 150v5.

- svakyi Si 122r1, 122r3, 148v5, 149r4, 149v5, 151r1.

- svakye Si 121v5, 151r1 (2×), 151r2, 151r4, 151r5 (2×).

- All occurrences of şvakā- are from the Siddhasāra. It translates Skt. varti 'suppository' and gudikā 'pill' and Tib. reng-bu and ri-lu 'pastil').

The first scholar to make known the word was H.W. Bailey (1935: 137). The striking correspondence with the Tocharian word was again noted by him some years later (Bailey 1947: 149). A further clarification of the meaning and the etymology is offered by R.E. Emmerick (1981: 221). ${ }^{63}$ There the meaning is established as 'suppository' against Bailey's 'pastil'. The etymology is given as < PIr. $x \check{s}$ audakā-, a formation from the root *xšaud- 'to wash' (Cheung 2007: 455). Since the word is a very specialized medical term, one should assume that the borrowing took place quite late, when Indian medical texts were already circulating within the Tarim basin. As it is attested only in the Late Khotanese Siddhasāra, the word was possibly borrowed from Late Khotanese, although it is not to be excluded that Old Khotanese translations of medical texts existed, even if they are no more extant. In this case, a possible

62 Skt. kardama- covers the whole semantic spectrum, see MW: 258 'mud, slime, mire, clay, dirt, filth'.

63 A summary is to be found also in SVK II: $147-8$ and DoT: 729. 


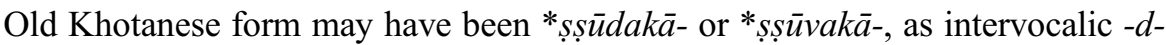
might have been lost already in Old Khotanese (see e.g. OKh. pāa-< PIr. *pa $d a-$ ). The preservation of intervocalic $-k$ - is noteworthy. The possibility that the Tocharian word was borrowed from Late Khotanese may seem more probable, as the nearest antecedent of the Tocharian initial cluster $s p$ - may have been LKh. $s v$ - rather than OKh. ${ }^{*} s \underline{u} \bar{u} v$-. Thus, TB spakiye must be considered a Late Khotanese loanword in Tocharian.

\subsection{TB sanapa- v. 'to rub in, rub on, anoint, embrocate (prior to washing)'} Tocharian occurrences:

- $\quad 3$ sg. pres. mid. sonopträ W40 b3 (se ce șalype sonopträ 'C' est cette huile qui est ointe' (Filliozat 1948: 88)).

- 3sg. opt. mid. sonopitär PK AS 6B a6 (sonopitär likșitär wästsanma krenta yäșsītär 'anointing himself, washing himself, [and] wearing beautiful clothes').

- $\quad$ pres. ger. sonopälle PK AS 8C b1 (partāktaññe pitkesa șarne s(o)nopäll (e) 'one has to smear both hands with spittle of viper [Vipera russelli]'), PK AS 9A b8 (se șälype mel(emn)e (yänmā)sșä«m» • tärne sonopälle 'This oil (reache)s the nos(trils). The crown of the head [is] to be anointed'), THT 497 b1, THT 2677.d b2, W7 b5, W26 b3, W40 b2.

- subj. ger. sanāpalle W27 b1 (mälkwersa kātsa sanāpalle 'à appliquer en onctions au ventre avec du lait' (Filliozat 1948: 85)), W35 a6, W39 a4, W41 b2.

- inf. sanāpatsi W4 b3, W14 a2, W29 b1, W34 a5.

- perl. san(āpo)rsa PK AS 8C b1 (san(āpo)rsa ka tweri rusenträ 'just by smearing the doors will open').

All occurrences are from medical texts.

Khotanese occurrences:

ysänāj-:

- 3sg. opt. OKh. Z 3.102, kho ju ye ysänājä nei'ṇa uysnauru samu 'as if one should bathe a being with nectar alone' (Emmerick 1968a: 69).

- inf. OKh. Z 24.220, ttī akșuttāndä pajsamä kädäna ysänājä 'then [they] began to bathe him to do him reverence' (Emmerick 1968a: 383).

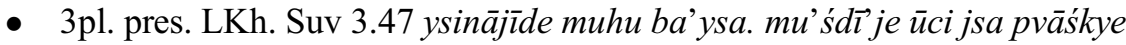
'may the Buddhas bathe me in the cool water of compassion' (Skjærvø 2004: I 49).

ysänāh-:

- 1sg. pres. LKh. P 2027.28 ysīnāha' (< OKh. *ysänāhe) 'I wash (off myself ?)' (Kumamoto 1991: 65).

- 3sg. pres. LKh. Jātakastava 6v1-2: tta khu ttaudäna hamthrrī satvä viysāmji ysināhe (< OKh. *ysināhätä) 'just as a man tormented by heat bathes in a lotus pool' (Dresden 1955: 424) and Sudhanāvadāna 373: haḍai sțām drai jūnäka aharști ysīnāhe 'Because of that she bathes three times a day' (De Chiara 2013: 151).

- $\quad$ part. nec. OKh. Suv 8.36: ysänāhāñu 'he should bathe' (Skjærvø 2004: I 189). 
- part. nec. in Siddhasāra 135v2 (as a medical term) LKh. vameysāñä $u$ ysin̄ạhāña 'must be massaged and bathed' (Emmerick unpublished), Sudhanāvadāna 235 and 233 (De Chiara 2013: 111, 139) and IOL Khot 160/4 v3 u drrai jūna hade ysināhāña 'and three times a day one should wash' (Skjærvø 2002: 359).

- 3pl. perf. tr. IOL Khot 147/1 r5 hamdāra ysinauttān $[d] \ddot{a}$ 'some washed (themselves)' (Skjærvø 2002: 331).

- $\quad$ past part. OKh. Suv 13.17+hu- 'well-' huysänauttī ttarandarä 'his body well-bathed' ${ }^{64}$



- 2sg. impv. P 5538b 88 rīmajsa pamūha ttai haysña 'dirty clothes. Wash.' (Kumamoto 1988: 69).

- 3sg. pres. OKh. Z 4.96 o kho käde rrīmajsi thauni kșārä biśśä haysñäte rrima 'or as when lye cleans all the dirt on a very dirty garment'. (Emmerick 1968a: 93).

- part. nec. LKh. as a medical term in Siddhasāra 100r5 haysñāña '(a medicinal herb) is to be washed'.

- 3sg. perf. tr. m. OKh. Z 2.170 pātro haysnāte 'he has washed the bowl' (Emmerick 1968a: 39), and 21.13 kvi ye haysnāte käde 'when one had washed it [the face] thoroughly' (Emmerick 1968a: 299), LKh. IOL Khot 75/4 b2 ${ }^{65}$ pā haysnātä 'he washed (his) feet', IOL Khot 28/14 b3-4 kamalä haysnā[te] 'he washed the head'. (Skjærvø 2002: 233).

- Past part. in the LKh. adj. haysnālīka- (KS: 309<haysnāta-+ suffix -lìka-) 'washed (of clothes)' in IOL Khot 140/1a6-7, 10, 11, $12 .{ }^{66}$

From the occurrences above, it seems that in Khotanese the three verbs had adopted three different semantic specializations: ysänāj- 'to wash, bathe another person', ysänāh- 'to wash, bathe oneself' and haysñ- 'to wash, clean a thing or a part of the body'. This gives a meaning which is slightly different from Tocharian 'to anoint'. Whereas haysñ- can be derived without difficulties from *fra-snā-ya (with past part. haysnāta- <*fra-snāta-) and ysänāh- from

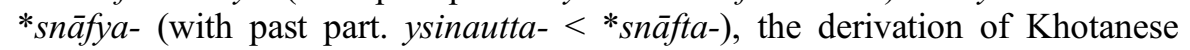
ysäna $j$ - is not straightforward. The $* k / g$ increment hypothesized by Bailey (DKS: 351) and Emmerick (SGS: 113) seems quite arbitrary and it is not attested in any other language (Cheung 2007: 348). The voiced fricative at the beginning of the word can be explained by the vicinity of $-n-$, so that we might have had

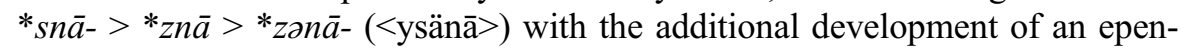
thetic $-\ddot{a}$-.

Adams (1988: 402-3) proposed that TB sanapa- 'to rub, anoint' 67 could be derived from the Pre-Khotanese antecedent of Khotanese ysänāh- 'to wash', i.e. from the stage at which Proto-Iranian intervocalic *-f- had still not shifted to $-h-$.

64 Skjærvø 2004: I 261. See further Suv 1.9 and 6.3 .16 with the same form.

$65=$ Ch.00275 (Vajracchedikā), see Skjærvø 2002: 302.

66 = Ch.cvi 001, see Skjærvø 2002: 321-2.

67 See also Peyrot (2013: 159) and Malzahn (2010: 934). No mention of it in Tremblay 2005. 
Since no $-f$ - exists in Tocharian, this could give only TB $-p$-. The vocalism he explains by arguing that the Khotanese verb was borrowed first as *senāp-, probably implying that the Khotanese vowel $-\ddot{a}$ - of the first syllable was pronounced as [e], i.e. a mid-front vowel. This vowel, however, is rather to be interpreted as [ə], since it occurs as an epenthetic vowel in unstressed position (Emmerick 1979: 442). Whatever the interpretation of the first vowel, however, there is no need to postulate a further metathesis (*senāp- >/sānep-/), as did Adams (1988: 403), since, if the verb was borrowed as senapa-, sanapa- may be simply obtained through $a$-umlaut.

In conclusion, Adams is probably correct in interpreting the word as a loan from Iranian. Further, it seems clear that sanapa- can only be derived from Pre-Khotanese, as this is the only Iranian language which has a $-p$ - increment to the root PIr. *snaH- (Cheung 2007: 348), no word-initial palatal, ${ }^{68}$ and an extra epenthetic vowel in the first syllable.

\section{Conclusion}

Of the twelve lexical items analysed, one (sanapa-) can be derived from Pre-Khotanese and nine (aìkwaș(t), eśpeșșe, kuñi-mot, tvāinkaro, ampa-, ampoño, krāke, krāk-, and spakīye) can be ascribed to Khotanese proper. Among these, tvānkaro is certainly an Old Khotanese borrowing. For eśpesșe, kuñi-mot, ampa-, ampoño (if not directly from ampa-), and spakiye a Late Khotanese origin can be posited, although for eśpesse this remains for now too uncertain. There is unfortunately no way to determine whether aíkwaș(t) and $k r a \bar{k} e$ (with its derivative $k r \bar{a} k$-) have been borrowed from Old or Late Khotanese. For the remaining two items (kuñcit and kurkamäsșe), an Iranian origin can be given as certain, although the dialect affiliation is still not completely clear.

I am aware of the fact that the dimensions of the analysed corpus are quite small. Nevertheless, from these results one may argue that contact between Khotanese and Tocharian took place uninterruptedly from prehistoric times until the epoch of the first written attestations. In particular, the medical lexicon may bear traces of contact both at an oral level in the Pre-Khotanese epoch and at a written level in the historical epoch. Five items that can be attributed to Khotanese proper, ampa-, ampoño, kuñi-mot, krāke and spakīye, are in fact technical terms which show a high level of semantic specialization. They must be assigned to a period in which Indian medical knowledge was already circulating widely in written form in both the South and North of the Tarim basin.

\section{Technical abbreviations}

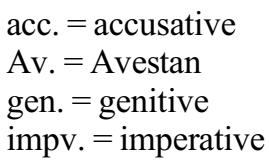

$$
\begin{aligned}
& \text { adj. }=\text { adjective } \\
& \text { com. }=\text { comitative } \\
& \text { ger. = gerundive } \\
& \text { inf. = infinitive }
\end{aligned}
$$

68 As New Persian šināvidan. I expect word-initial $\check{s}$ - to remain unchanged in Tocharian, represented by $s$-. 




\section{Bibliographic abbreviations}

CDIAL $=$ Turner 1962-85

$\mathrm{CPD}=$ MacKenzie 1971

DKS = Bailey 1979

DoT $=$ Adams 2013

EDP $=$ Morgenstierne 2003

$\mathrm{EVSh}=$ Morgenstierne 1974

EWA $=$ Mayrhofer 1992-2001

GMS $=$ Gershevitch 1954

KEWA I-IV = Mayrhofer 1956-80

KS = Degener 1989

KT I-VII = Bailey 1945-85

MW = Monier-Williams 1899

SDTV = Emmerick and Vorob'ëva-Desjatovskaja 1995

SelPap I-II = Henning 1977

$\mathrm{SGS}=$ Emmerick 1968b

SVK I = Emmerick and Skjærvø 1982

SVK II = Emmerick and Skjærvø 1987

\section{References}

Adams, Douglas Q. 1988. "The formation of Tocharian B kalāk- 'to follow,' parāk- 'to rejoice,' sanāp- 'to anoint,' and walāk- 'to dwell,' with some observations on the development of Proto-Indo-European laryngeals in Tocharian", in Yoël L. Arbeitman (ed.), A Linguistic Happening in Memory of Ben Schwartz: Studies in Anatolian, Italic, and other Indo-European languages. Louvain-la-Neuve: Peeters, 401-10.

Adams, Douglas Q. 2013. A Dictionary of Tocharian B. Revised and Greatly Enlarged. 2nd ed. Amsterdam; New York: Rodopi.

Bailey, Harold W. 1935. "Iranian studies, V", Bulletin of the School of Oriental Studies 8/1, 117-42, 919-20. 
Bailey, Harold W. 1937. "Ttaugara”, Bulletin of the School of Oriental Studies 8/4, 883921.

Bailey, Harold W. 1945-85. Khotanese Texts. Vol. 1 (1945); vol. 2 (1954); vol. 3 (1956) [vols 1-3, 2nd ed. 1969 in one volume; repr. 1980]; vol. 4 (1961) [repr. with corrections 1979]; vol. 5 (1963) [repr. with corrections 1980]; vol. 6 (1967); vol. 7 (1985). Cambridge: Cambridge University Press.

Bailey, Harold W. 1946. "Gāndhārı̄”, Bulletin of the School of Oriental and African Studies 11/4, 764-97.

Bailey, Harold W. 1947. "Recent work in 'Tokharian"”, Transactions of the Philological Society 46/1, 126-53.

Bailey, Harold W. 1957. "Dvāra matīnām", Bulletin of the School of Oriental and African Studies 20/1, 41-59.

Bailey, Harold W. 1979. Dictionary of Khotan Saka. Cambridge: Cambridge University Press.

Barbati, Chiara. 2016. The Christian Sogdian Lectionary E5 in Context. (Sitzungsberichte der Phil.-Hist. Klasse 874, Veröffentlichungen zur Iranistik 81.) Vienna: Verlag der Österreichischen Akademie der Wissenschaften.

Baxter, William H. and Laurent Sagart. 2014. Old Chinese: A New Reconstruction. New York: Oxford University Press.

Benveniste, Émile. 1940. Textes Sogdiens. (Mission Pelliot en Asie centrale 3.) Paris: Geuthner.

Benveniste, Émile. 1946. Vessantara Jātaka, Texte Sogdien Édité, Traduit et Commenté. (Mission Pelliot en Asie centrale 4.) Paris: Geuthner.

Bernard, Chams B. 2020. "Some plant and animal names in Gavruni", in Romain Garnier (ed.), Loanwords and Substrata. Proceedings of the Colloquium Held in Limoges, $5^{\text {th }}-7$ th June, 2018. Innsbruck: Institut für Sprachwissenschaft, 27-61.

Bielmeier, Roland. 2012. "Ginger: a Khotanese loanword in modern Purik-Tibetan", in Cristina Scherrer-Schaub (ed.), Old Tibetan Studies Dedicated to the Memory of R.E. Emmerick: Proceedings of the Tenth Seminar of the IATS, 2003. (Brill's Tibetan Studies Library 10.14.) Leiden and Boston: Brill, 21-7.

von Böhtlingk, Otto and Rudolph von Roth. 1855-75. Sanskrit Wörterbuch (7 vols). St. Petersburg: Eggers.

Canevascini, Giotto. 1993. The Khotanese Sanghātasūtra. A Critical Edition. (Beiträge zur Iranistik 14.) Wiesbaden: Reichert.

Carling, Gerd. 2003. "Fragments bilingues du Yogaśataka. Révision commentée de l'édition de Jean Filliozat", Tocharian and Indo-European Studies 10, 37-68.

Carling, Gerd. 2007. "The vocabulary of Tocharian medical manuscripts", Asian Medicine 3, 323-33.

Carling, Gerd, Georges-Jean Pinault, and Werner Winter. 2009. A Dictionary and Thesaurus of Tocharian A. Volume 1: Letters A-J. Wiesbaden: Harrassowitz.

Cheung, Johnny. 2007. Etymological Dictionary of the Iranian Verb. (Leiden Indo-European Etymological Dictionary Series 2.) Leiden and Boston: Brill.

De Chiara, Matteo. 2013. The Khotanese Sudhanāvadāna. (Beiträge zur Indologie 48.) Wiesbaden: Harrassowitz.

Degener, Almuth. 1987. "Khotanische Komposita", Münchener Studien zur Sprachwissenschaft 48, 27-69.

Degener, Almuth. 1989. Khotanische Suffixe. (Alt- und Neu-Indische Studien herausgegeben vom Institut für Kultur und Geschichte Indiens und Tibets an der Universität Hamburg 39.) Stuttgart: Franz Steiner. 
Dresden, Mark J. 1955. The Jätakastava or "Praise of the Buddha's former births": Indo-Scythian (Khotanese) Text, English Translation, Grammatical Notes and Glossaries. (Transactions of the American Philological Society, n.s. 45.5.) Philadelphia: The American Philosophical Society.

Duan Qing. 1992. Das khotanische Aparimitāyuhsūtra: Ausgabe, Übersetzung, Kommentar und Glossar. (Studien zur Indologie und Iranistik. Dissertationen 3.) Reinbek: Dr. Inge Wezler.

Durkin-Meisterernst, Desmond. 2014. Grammatik des Westmitteliranischen (Parthisch und Mittelpersisch). (Sitzungsberichte der phil.-hist. Klasse 850, Veröffentlichungen zur Iranistik 73, Grammatica Iranica, Band 1.) Vienna: Verlag der Österreichischen Akademie der Wissenschaften.

Emmerick, Ronald E. Unpublished manuscript. Edition of the Late Khotanese Siddhasāra.

Emmerick, Ronald E. 1968a. The Book of Zambasta, A Khotanese Poem on Buddhism. (London Oriental Series 21.) London: Oxford University Press.

Emmerick, Ronald E. 1968b. Saka Grammatical Studies. (London Oriental Series 20.) London: Oxford University Press.

Emmerick, Ronald E. 1970. The Khotanese Śurañgamasamādhisūtra. (London Oriental Series 23.) London: Oxford University Press.

Emmerick, Ronald E. 1979. "The vowel phonemes of Khotanese", in Bela Brogyanyi (ed.), Studies in Diachronic, Synchronic, and Typological Linguistics: Festschrift for Oswald Szemerényi on the Occasion of His 65th Birthday. (Amsterdam Studies in the Theory and History of Linguistic Science 4.2.) Amsterdam: Benjamins, 239-50.

Emmerick, Ronald E. 1980. The Siddhasāra of Ravigupta, 1: The Sanskrit Text. (Verzeichnis der orientalischen Handschriften in Deutschland, Supplementband 23.1.) Wiesbaden: Steiner.

Emmerick, Ronald E. 1981. "The case against ș-", Indogermanische Forschungen 86, 212-22.

Emmerick, Ronald E. 1982. The Siddhasāra of Ravigupta, 2: The Tibetan Version with Facing English Translation. (Verzeichnis der orientalischen Handschriften in Deutschland, Supplementband 23.2.) Wiesbaden: Steiner.

Emmerick, Ronald E. 1983. "Some remarks on translation techniques of the Khotanese", in Klaus Michael Röhrborn and Wolfgang Veenker (eds), Sprachen des Buddhismus in Zentralasien: Vorträge des Hamburger Symposions vom 2. Juli bis 5. Juli 1981. (Veröffentlichungen der Societas uralo-altaica 16.) Wiesbaden: Harrassowitz, 17-26.

Emmerick, Ronald E. 1985. "Tibetan loanwords in Khotanese and Khotanese loanwords in Tibetan", in Gherardo Gnoli and Lionello Lanciotti (eds), Orientalia Iosephi Tucci Memoriae Dedicata. (Serie orientale Roma 56.1.) Rome: Istituto italiano per il Medio ed Estremo Oriente, 301-17.

Emmerick, Ronald E. 1986. “'Ruki' in Khotanese?”, in Rüdiger Schmitt and Prods Oktor Skjærvø (eds), Studia Grammatica Iranica. (Münchener Studien zur Sprachwissenschaft. Beiheft 13, neue Folge.) Munich: Kitzinger, 71-81.

Emmerick, Ronald E. 1989. "Khotanese and Tumshuqese", in Rüdiger Schmitt (ed.), Compendium Linguarum Iranicarum. Wiesbaden: Reichert, 204-29.

Emmerick, Ronald E. and Prods O. Skjærvø. 1982. Studies in the Vocabulary of Khotanese I. (Veröffentlichungen der iranischen Kommission 12.) Vienna: Verlag der Österreichischen Akademie der Wissenschaften.

Emmerick, Ronald E. and Prods O. Skjærvø. 1987. Studies in the Vocabulary of Khotanese II. (Veröffentlichungen der iranischen Kommission 16.) Vienna: Verlag der Österreichischen Akademie der Wissenschaften. 
Emmerick, Ronald E. and Margarita I. Vorob'ëva-Desjatovskaja. 1995. Saka Documents, Text Volume III: The St. Petersburg Collections. (Corpus Inscriptionum Iranicarum, Part II Inscriptions of the Seleucid and Parthian Periods and of Eastern Iran and Central Asia, Vol. V Saka.) London: School of Oriental and African Studies.

Filliozat, Jean. 1948. Fragments de Textes Koutchéens de Médecine et de Magie. Paris: Librairie d'Amérique et d'Orient Adrien-Maisonneuve.

Gershevitch, Ilya. 1954. A Grammar of Manichean Sogdian. Oxford: Basil Blackwell.

Gharib, Badr al-Zamān. 1995. Sogdian Dictionary: Sogdian-Persian-English. Tehran: Farhangan.

Hassandoust, Mohammad. 2015. Farhang-e riše-šenahti-ye zabān-e fārsi [The Etymological Dictionary of Persian] (5 vols). Tehran: Academy of Persian Language and Literature.

Henning, Walter B. 1946. "The Sogdian texts of Paris", Bulletin of the School of Oriental and African Studies 11/4, 713-40 [= SelPap II: 231-58].

Henning, Walter B. 1965. "A grain of mustard", Annali dell'Istituto Universitario Orientale di Napoli, Sezione linguistica 6, 29-47 [= SelPap II: 597-618].

Henning, Walter B. (M. Boyce et al. eds). 1977. Selected Papers, I-II. (Acta Iranica, 2. sér, 14-15; Hommages et Opera Minora, V-VI.) Tehran and Liège: Brill.

Isebaert, Lambert. 1980. De Indo-Iraanse Bestanddelen in de Tocharische Woordenschat. Unpublished $\mathrm{PhD}$ dissertation, University of Leuven.

Korn, Agnes. 2005. Towards a Historical Grammar of Balochi. Studies in Balochi Historical Phonology and Vocabulary. (Beiträge zur Iranistik 26.) Wiesbaden: Reichert.

Kumamoto, Hiroshi. 1988. "Sei-iki ryokōshayō sansukuritto-kōtango kaiwa renshūchō" [A Sanskrit-Khotanese Conversation Manual for Central Asian Travellers], Seinan Ajia kenkyū 28, 53-82.

Kumamoto, Hiroshi. 1991. "Some Khotanese letters in verse", Tokyo University Linguistic Papers 12, 59-80.

Kümmel, Martin J. 2018. "The survival of laryngeals in Iranian”, in Lucien van Beek, Alwin Kloekhorst, Guus Kroonen, Michaël Peyrot, Tijmen Pronk and Michiel de Vaan (eds), Farnah. Indo-Iranian and Indo-European Studies in Honor of Sasha Lubotsky. Ann Arbor and New York: Beech Stave Press, 162-72.

Laufer, Berthold. 1916. "Loan-words in Tibetan", T oung Pao 17/1, 403-552.

Laufer, Berthold. 1919. Sino-Iranica. Chinese Contributions to the History of Civilization in Ancient Iran. Chicago: Field Museum of Natural History.

Luzzietti, Silvia. 2018-19. Il Pindaśástra: saggio di edizione con traduzione, commento e glossario di un testo āyurvedico cotanese. Unpublished MA thesis, Università La Sapienza, Rome.

MacKenzie, David N. 1971. A Concise Pahlavi Dictionary. London: Oxford University Press.

Maggi, Mauro. 2008. "A Khotanese medical text on poultices: manuscripts P 2893 and IOL Khot S 9", Traditional South Asian Medicine 8, 77-85.

Maggi, Mauro. 2009. "Khotanese literature", in Ronald E. Emmerick and Maria Macuch (eds), The Literature of Pre-Islamic Iran, Companion Volume I to A History of Persian Literature. London and New York: I.B. Tauris, 330-418.

Maggi, Mauro. 2018. "Bits and bites: the Berlin fragment bi 43 and Khotanese *druṣ-", Annual Report of The International Research Institute for Advanced Buddhology at Soka University 22, 247-60, plates 4-5. 
Maggi, Mauro. 2019. "Morphology of the Khotanese verbs in -Vș-", Linguistica e Filologia 39, 43-62.

Malzahn, Melanie. 2007. "The most archaic manuscripts of Tocharian B and the varieties of the Tocharian B language", in Melanie Malzahn (ed.), Instrumenta Tocharica. Heidelberg: Winter, 255-97.

Malzahn, Melanie. 2010. The Tocharian Verbal System. (Brill's Studies in Indo-European Languages \& Linguistics 3.). Leiden and Boston: Brill.

Maue, Dieter. 1990. "Das Mahāvaidehikam ghrtam in Tocharisch B", Historische Sprachforschung 103, 159-65.

Mayrhofer, Manfred. 1956-80. Kurzgefaßtes etymologisches Wörterbuch des Altindischen (4 vols). (Indogermanische Bibliothek. 1. Abt., Sammlung indogermanischer Lehr- und Handbücher. 2. Reihe: Wörterbücher.) Heidelberg: Carl Winter.

Mayrhofer, Manfred. 1992-2001. Etymologisches Wörterbuch des Altindoarischen (3 vols). (Indogermanische Bibliothek. 1. Abt., Sammlung indogermanischer Lehrund Handbücher. 2. Reihe: Wörterbücher.) Heidelberg: Carl Winter.

Monier-Williams, Monier. 1899. A Sanskrit-English Dictionary. Etymologically and Philologically Arranged with Special Reference to Cognate Indo-European Languages. New Edition, Greatly Enlarged and Improved. Oxford: Clarendon Press.

Morgenstierne, Georg. 1927. An Etymological Vocabulary of Pashto. (Skrifter utgitt av det Norske Videnskapsakademi i Oslo. II, Historisk-filosofisk Klasse 3.) Oslo: Dybwad.

Morgenstierne, Georg. 1974. Etymological Vocabulary of the Shughni Group. (Beiträge zur Iranistik 6.) Wiesbaden: Reichert.

Morgenstierne, Georg. 2003. A New Etymological Vocabulary of Pashto. Compiled and Edited by J. Elfenbein, D.N. MacKenzie and Nicholas Sims-Williams. (Beiträge zur Iranistik 23.) Wiesbaden: Reichert.

Peyrot, Michaël. 2008. Variation and Change in Tocharian B. (Leiden Studies in Indo-European 15.) Amsterdam and New York: Rodopi.

Peyrot, Michaël. 2010. "On the formation of the Tocharian preterite participle", Historische Sprachforschung 121, 69-83.

Peyrot, Michaël. 2013. The Tocharian Subjunctive. A Study in Syntax and Verbal Stem Formation. (Brill's Studies in Indo-European Languages \& Linguistics 8.) Leiden and Boston: Brill.

Peyrot, Michaël. 2014. "La relation entre la chronologie du Tokharien B et la paléographie", Eurasian Studies 12, 121-47.

Peyrot, Michaël. 2015. "Tocharian language", in Encyclopcedia Iranica, online edition, available at http://www.iranicaonline.org/articles/tocharian-language (accessed on 27 July 2015).

Peyrot, Michaël. 2018. "Tocharian B etswe 'mule' and Eastern East Iranian”, in Lucien van Beek, Alwin Kloekhorst, Guus Kroonen, Michaël Peyrot, Tijmen Pronk and Michiel de Vaan (eds.), Farnah. Indo-Iranian and Indo-European Studies in Honor of Sasha Lubotsky. Ann Arbor and New York: Beech Stave Press, 270-83.

Rastorgueva, Vera S. and Džoj I. Èdel'man. 2000. Ėtimologičeskij slovar' iranskix jazykov [Etymological Dictionary of Iranian languages]. Vol. 1: a-ā. Moscow: Vostočnaja literatura.

Reck, Christiane and Adam Benkato. 2018. “'Like a virgin': a Sogdian recipe for restoring virginity and the Sanskrit background of Sogdian medicine", Written Monuments of the Orient 8/2, 67-91.

Reck, Christiane and Jens Wilkens. 2015. "Soghdische Versionen von Vāgbhațas Aștāngahṛdaya-saṃhitā", in Elisabetta Ragagnin and Jens Wilkens (eds), Kutadgu 
Nom Bitig. Festschrift für Jens Peter Laut zum 60. Geburtstag. (Veröffentlichungen der Societas uralo-altaica 87.) Wiesbaden: Harrassowitz, 431-52.

Röhrborn, Klaus. 1979. Uigurisches Wörterbuch. Sprachmaterial der vorislamischen türkischen Texte aus Zentralasien. Lieferung 2 agrlglan- - anta. Wiesbaden: Franz Steiner.

Ross, Alan S.C. 1952. Ginger, a Loan-Word Study. Oxford: Blackwell.

Sims-Williams, Nicholas. 1983. "Chotano-Sogdica", Bulletin of the School of Oriental and African Studies 46/1, 40-51.

Sims-Williams, Nicholas and James Hamilton. 1990. Documents turco-sogdiens du IX $X^{\mathrm{e}}$ siècle de Touen-houang. (Corpus Inscriptionum Iranicarum. Part II: Inscriptions of the Seleucid and Parthian Periods and of Eastern Iran and Central Asia. Vol. 3 Sogdian.) London: School of Oriental and African Studies.

Skjærvø, Prods O. 1994. "Of lice and men and the Manichean anthropology", in Renate Söhnen-Thieme and Oskar von Hinüber (eds), Festschrift Georg Buddruss. (Studien zur Indologie und Iranistik 19.) Reinbek: Dr. Inge Wezler, 269-86.

Skjærvø, Prods O. 2002. Khotanese Manuscripts from Chinese Turkestan in the British Library. (Corpus Inscriptionum Iranicarum. Part II: Inscriptions of the Seleucid and Parthian Periods and of Eastern Iran and Central Asia. Vol. 5: Saka, Texts 6.) London: The British Library.

Skjærvø, Prods O. 2004. This Most Excellent Shine of Gold, King of Kings of Sutras: the Khotanese Suvarnabhāsottamasütra. Vol. I: The Khotanese Text with English Translation and the Complete Sanskrit Text. Vol. II: Manuscripts, Commentary, Glossary, Indexes. (Sources of Oriental Languages and Literatures, 60 and 61. Central Asian Sources V and VI.) Cambridge, MA: The Department of Near Eastern Languages and Civilizations, Harvard University.

Thomason, Sarah G. 2001. Language Contact. Edinburgh: Edinburgh University Press.

Tremblay, Xavier. 2005. "Irano-Tocharica et Tocharo-Iranica", Bulletin of the School of Oriental and African Studies 68/3, 421-49.

Van Windekens, Albert J. 1949. "Études iraniennes et tokhariennes I-II”, Muséon 62, 125-50, 261-74.

Turner, Ralph L. 1962-85. A Comparative Dictionary of the Indo-Aryan Languages. London and New York: Oxford University Press.

Zieme, Peter. 2007. "Notes on Uighur medicine, especially on the Uighur Siddhasāra tradition", Asian Medicine 3, 308-22. 